\title{
Shprintzen-Goldberg syndrome
}

INSERM

\section{Source}

INSERM. (1999). Orphanet: an online rare disease and orphan drug data base. Shprintzen-

Goldberg syndrome. ORPHA:2462

Shprintzen-Goldberg syndrome (SGS) is a very rare genetic disorder characterized by craniosynostosis, craniofacial and skeletal abnormalities, marfanoid habitus, cardiac anomalies, neurological abnormalities, and intellectual disability. 